\title{
Kreativitás és valóság a gazdálkodás eredményének meghatározásában
}

\author{
Wickert Irén, ${ }^{1}$ Szarvas-Fekete Tibor, ${ }^{2}$ Ágoston Anita $^{3}$
}

\begin{abstract}
Creativity and Reality in Determining the Outcome of Management. The determining of the outcome periodically is primary important in the operation of businesses. The assets and their changes, as well as the profit generating efficiency, ensure that the business continues to operate. In Hungary the Act Cof 2000 on Accounting defines the method of accounting for economic events; however, the practice the accounting, which is based on experience, can make a move towards the creativity. The principle, which is not forbidden by the law, that is "free". The interpretation and recording of economic events and the judgement of their impact on outcome can often be based on subjective assessment. This article deals with the effects of subjective judgment and choosing on the results.
\end{abstract}

Keywords accounting, result, practice, creativity

\section{Bevezetés}

Hazánkban a gazdálkodók működésének nyilvántartására, a gazdasági események elszámolására vonatkozó jogi szabályokat a Számvitelról szóló 2000. évi C. törvény tartalmazza. Ez alapján a számvitel célja információ szolgáltatás az érdekelteknek a jövőbeni döntéseik megalapozásához. Már ez a mondat is magában foglalja, hogy a vállalkozás müködésére vonatkozó információk milyen fontosak, és az esetleges eltérések az elszámolásokban akár rossz döntés ekhez is vezethetnek.

A vállalkozások müködésük során számos külső partnerrel, belső érdekhordozó val kapcsolatba kerülnek, akik meg szeretnék ismerni a cég müködését, a gazdálkodásra vonatkozó főbb adatokat, és az eredményesség alakulását. Ezen feladat elvégzése érdekében a számvitel keretén belül elvégzik a gazdasági események megfigyelését, mérését, feljegyzését, ellenőrzését, elemzését és a beszámoló készítését.

${ }^{1}$ Kaposvári Egy etem, Gazdaságtudományi Kar

E-mail: wickert.iren@ke.hu

2 Kaposvári Egy etem, Gazdaságtudományi Kar E-mail: szarvasfekete.tibor@ke.hu

${ }^{3}$ Kaposvári Egy etem, Gazdaságtudományi Kar E-mail: agoston.anita@ke.hu 
A kreatív számvitel fogalmát sokan negatív értelemben használják, és azonosítják a csalással, a teljesítmények torzításával és a beszámolók meghamísításával. A Naser (1993) által megfogalmazott definíció szerint a kreatív számvitel olyan folyamat, amelyben a szabályozásban lévő rések kihasználásával olyan mérési és értékelési módszereket alkalmaznak, amelyek a pénzügyi beszámolókat a menedzsmentnek megfelelően alakítják.

A kreatív számvitel nemazonos a csalással. A könyvelés adatainak és az eredmény alakulásának megváltoztatása történhet törvényes keretek között és illegális módon is az elérendő cél tükrében. A kreatív könyvelés célja lehet a lopás, a csalás, az adóelkerülés, melyek a gazdasági büncselekmények kategóriájába tartoznak. Ezen kívül azonban a számviteli elszámolásokban megvalósított kreatív megoldások irányulhatnak a müködés racionalizálására is, miközben megfelelnek a Számviteli törvény által megfogalmazott elóírás oknak is.

A gazdasági válság kirobbanása után bebizonyosodott, hogy az ezredfordulót követően számos amerikai vállalat beszámolóját meghamisították, illetve torzították az adatokat. A számviteli csalás és az adóelkerülés azonban nem csak a külföldi cégeket érinti, hanem találkozhatunk a problémával a magyar vállalkozások elemzése során is. Cikkünk első része a hazai vállalkozások müködésében leggyakrabban előforduló gazdasági csalásokat mutatja be

A törvény adta kereteken belül azonban a vállalkozások a gyakorlatban a korábbi tapasztalataikból kiindulva bizonyos problémákat eltérő szemszögből közelítenek meg, illetve másképpen oldanak meg, mely végül befolyásolja az elöállított információkat, a gazdálkodás eredményességét, és a partnerek cégre vonatkozó véleményét. A különböző megoldások skálája széles lehet a számviteli szakember fantáziája és kreativitása tükrében.

Az eltérő eljárások, könyvelési megoldások és elszámolások nem jelentik azt, hogy a vállalkozás szabálytalanul müködik, csalást követ el a nyilvántartásokban, csupán a törvény elöírásait betartva a tevékenységhez leginkább illö, az eredmény szempontjából legkedvezőbb megoldást válas ztja az elszámolások során.

A Számviteli törvény által biztosított lehetőségek maximális kihasználása érdekében a vállalkozásoknak a tevékenységüknek leginkább megfelelő számviteli politikát kell kialakítaniuk. Ebben kell szabályozni számos olyan elszámolási módszert, eljárást, mely a későbbiekben nagy mértékben befolyásolja az eredményesség alakulását. Cikkünk második részében ezen legális lehetőségek tárházát szeretnénk bemutatni a gyakorlati tapasztalatok alapján.

\section{Gazdasági visszaélés ek}

A vállalkozások müködésében tapas ztalt csalásoknak rendkívül sok fajtája létezik a gyakorlatban. Az ISA240 Nemzetközi Könyvvizsgálati Standard a csalást a következő módon definiálja. „A vezetés egy vagy több tagja, az irányításért felelös személyek, a munkavállalók vagy harmadik felek közül valamely személy(ek) által szándékosan elkövetett cselekedet, amely együtt jár a méltánytalan vagy illegális előny szerzése céljából alkalmazott megtévesztéssel" (ISA240, 2008).

A csalás létrejöttéhez három tényezőnek kell együttesen fennállnia (1. ábra). A motivációnak, vagy a külső nyomásnak; az önigazolásnak és a lehetőségnek. 


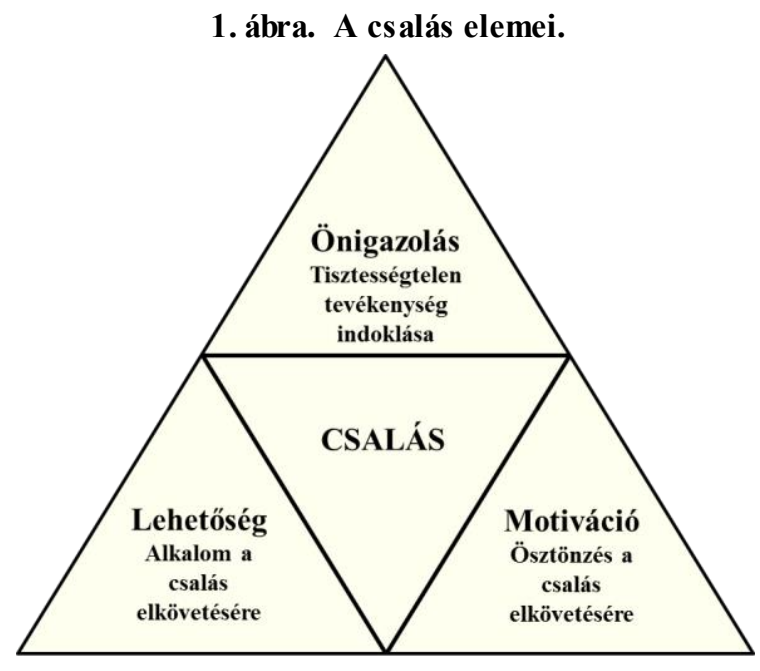

Forrás: Veit, 2014

- A motiváció vagy a külső nyomás sokszor az egyén nehéz életkörülményeivel, vagy egy nehéz élets zakasszal hozható kapcsolatba. Ilyen lehet egy személyes pénzügyi probléma, a munkáltató felöl érkező kimagasló eredményeket elváró nyomás, de akár magánéleti probléma is állhat a csalás hátterében.

- Az önigazolást kiválthatja a nem megfelelő vállalati kultúra és értékrend. Ha olyan vezetők állnak a cég élén, akik nem rendelkeznek megfelelő szaktudással a fontos pénzügyi és számviteli kérdésekben, akkor az alkalmazottak saját gyakorlati tapas ztalataik alapján könnyebben tudnak csalást elkövetni.

- A lehetőség akkor alakul ki, ha az elkövető bizalmi pozíciót tölt be, átlátja a vállalkozás müködését, így tisztában van az esetleges hiányosságokkal.

A csalási hároms zög ,megszakítása” a kulcsa a csalás megelőzésének. Ha az egyik hiányzik, akkor nem valósul meg a gazdasági büncselekmény. A három elem közül a lehetőség az, amit a vállalkozás a leginkább befolyásolni tud a belső kontroll rendszer működtetése által, így elkerülhetővé válik a gazdasági vis szaélés és csalás. (Cendrowski et al., 2007)

El kell különíteni, hogy a céggel kapcsolatban állók, pl.: munkavállalók, piaci partnerek, vagy maguk a tulajdonosok, menedzserek állnak-e a tevékenység mögött. A vállalati visszaélések azonban egy súlyos problémát vetnek fel, melynek elkerülése és felismerése napjaink központi kérdése. A visszaélések kiemelt jelentőséggel bírnak, mivel az erre vonatkozó statis ztikák azt mutatják, hogy átlagosan az árbevétel 5\%-át érintik, és a veszteségek $58 \%$-át nem sikerül behajtani, visszaszerezni. Magyarországon a vállalatok 26 százalékánál fedeztek fel gazdasági visszaélést, mely az esetek többségében csupán véletlenszerüen derült ki (ACFE, 2016).

A csalásból származó károk enyhítésére, illetve elkerülésére számos megoldási lehetőséget alkalmaznak a vállalkozások.

- Hatékonyabb kontrolling rendszer kialakítása, müködtetése során a csalások hossza és az érintett pénzösszeg statisztikailag alacsonyabb, így az ellenőrzésbe fektetett ráfordítások hatékonyan megtérülnek.

- Az etikai forródrót müködtetése egy viszonylag új megoldás, és hazánkban még nem elterjedt, azonban a nemzetközi adatok azt bizonyítják, hogy ebben 
az esetben is csökkentek a csalásból származó negatív következmények. A forródrót alkalmazása mellett a visszaélések sokkal hamarabb kiderültek (közel fele annyi idő alatt, mint a többi vállalat esetében), és a 41\%-kal kevesebb vesztess éggel zárultak.

Az Okleveles Csalást Vizsgálók Szövetsége (ACFE) a csalásokat három fö csoportba sorolja, melyeket további alkategóriákra osztja az alábbi bontásban:

- Korrupció
○ Összeférhetetlenség
- Beszerzési
- Értékesítési
- Egyéb
○ Megvesztegetés
- Csúszó- és kenőpénz
- Tendermanipulálás
- Egyéb
○ Jogosulatlan elönyök
- Gazdasági zsarolás

- Eszközök hütlen kezelése

○ Pénzeszközök

- Lopás (házpénztárból, els zámolási betéts zámláról, egyéb)

- Kifizetésekkel kapcsolatos csalások

> Számlázás (fiktív, személyes célú beszerzés)

$>$ Bérs zámfejtés (szellemi dolgozó, jutalék, fiktív, hamisított bérek)

> Költség els zámolások (rosszul kategorizált költségek, valós értéket meghaladó elszámolások, fiktív költségek, többszörös elszámolás)

> Csekkhamisítás (visszaélés az aláíró nevével, hamis forgatmányos, megváltoztatott kedvezményezett, hamis csekk, felhatalmazott aláíró)

Pénztári kiadások (fiktív bevétel érvénytelenítés, fiktív vevői visszatérítés)

- Lefölözés

$>$ Értékesítés (nem rögzített, alulértékelt)

$>$ Követelések (leírás)

$>$ Visszatérítések és egyéb

○ Nem pénzes zközök

- Nem megfelelö felhasználás

- Lopás (eszköz trans zferrel kapcsolatos, fiktív eladás és szállítás, beszerzés és hamisított átvétel)

- Hamisított beszámolók

○ Pénzügyi

- Eszközök és források túlértékelése

- Eszközök és források alulértékelése

- Időzítési különbségek

- Fiktív bevételek

- Nem lekönyvelt költségek, kötelezettségek

- Nem megfelelő nyilvánosságra hozatal 
○ Nem pénzügyi

- Munkavállalói adatok, referenciák

- Belső dokumentumok

- Külső dokumentumok (ACFE, 2016)

Egy gazdaságibűnözés ről szóló nemzetközi felmérés alapján ezen problémák hazánkat semkerülik el, annak ellenére, hogy a Számviteli törvény keretein belül a vállalkozás oknak legális an is van lehetőségük azeredmény befolyásolására. Azelmúlt években a gazdasági vis szaélés ek s záma csökkent, míg 2001-ben a hazai vállalkozás ok egyharmada találkozott gazdasági büncselekménnyel, addig ez az arány 2015-re 25\%-ra csökkent.

2015-ben „Magyarors zágon azöt leggyakrabban előforduló gazdasági büncselekmény a hütlen kezelés (46\%), a korrupció és vesztegetés (38\%), azadócsalás (21\%), a számítógépes bűnözés (17\%), valamint a közbeszerzési csalás ok (17\%).” (PwC, 2016) Míg a globális adatok azt mutatják, hogy a vállalat alkalmazottainakjelentős szerepe van a csalás ok elkövetésében, azesetek 56 százalékában belső elkövetőt azonosítottak, addig Magyarországon jóval kedvezőbb arányokkal találkozhatunk. A csalók 54\%-a külső elkövető, 38\%-a a vállalaton belül foglalkoztatott, és az esetek $8 \%$-ában nemismert a kilétük. A vizs gálat alapján, melybe 95 hazai vállalat vezető beosztású munkatársát vonták be, a vállalaton belüli tipikus cs aló széleskörü elméleti és gyakorlati tapas ztalattalés tudás sal rendelkezik, jellemzöentöbb diplomát szerzett már, 41 és 50 év közötti férfi, akit már több mint 6 éve foglalkoztatnak a vállalkozás ban (PwC, 2016).

Hazánkban a leggyakrabban előforduló számviteli csalások közé a fiktív bevételek és a fiktív kiadások tartoznak. A fiktív bevételek esetében az alábbi tevékenységet azonosított jellemzően:

- A profit növelése érdekében nem létező vevőknek (fantom cégeknek) értékesítenek.

- Számlát állítanak kis valós vevőknek, azonban tényleges áruszállítás, vagy szolgáltatásnyújtás nem kapcsolódik az ügylethez.

- Az eredmény növelése érdekében a bevételeket határidő előtt számolják el.

- Nem állítottak ki helyes bítő számlát annak ellenére, hogy az árut vis szaküldték. A fiktív kiadások is a csalások ,népszerü" körébe tartoznak. Például, ha a költségeket nem a megfelelő időszakra könyvelik el, vagy bizonyos kiadásokat, illetve kötelezettségeket nem könyvelnek el.

A gazdasági büncselekmények számának csökkentése érdekében a hazai számviteli törvény mozgásteret enged a vállalkozásoknak, hogy a számviteli politikájukat úgy alakítsák ki, hogy a tevékenység jellegéhez leginkább igazodjon. Ennek eredményeképpen törvényes módon is lehet befolyásolni az eredmény alakulását a következő fejezetben vázolt megoldásokkal.

\section{Kreatív számviteli megoldások a Számviteli törvény keretein belül}

A számvitel szabályozása keretjellegű, nem terjed ki valamennyi gazdasági eseményre. A törvény által biztosított választási lehetőségeket a gazdálkodóknak kell rendezni a számviteli politikában (Lakatos et al. 2013).

Számviteli politika:

- A gazdálkodó a beszámoló készítése és bemutatása során alkalmazott, a vállalkozásra jellemző szabályok, elöírások, módszerek és követett gyakorlat, 
amelyek befolyásolják az eredményt és hatással vannak a vagyoni, pénzügyi és jövedelmi helyzetre.

- A vezetés szabad válas ztására akkor kerülhet sor, ha nincs konkrét szabályozás valamely gazdasági eseménnyel kapcsolatban.

A számviteli politika kialakítása során alkalmazni kell a következetesség elvét.

A jogszabály adta lehetőség kihasználása a részben az eredményre vannak hatással, részben a vállalati vagyon és saját tőke nagyságát befolyásolják.

\section{Aktiválás - költségként való elszámolás}

A vállalkozás döntésétől függ, hogy az alapítás, átszervezés valamint a kísérleti fejlesztés felmerült és a jövőben várhatóan hasznosuló közvetlen költségét elszámolja az adott időszak eredménye terhére, vagy aktiválja.

A számviteli törvény alapján az immateriális javak között szerepel az alapítás -átszervezés aktivált értéke és a kísérleti fejlesztés aktivált értéke is.

- „Alapítás-áts zervezés aktivált értékeként a vállalkozási tevékenység indításával, megkezdésével, jelentős bővítésével, átalakításával, átszervezésévelkapcsolatos beruházásnak, felújításnak nem minősülő - a külső vállalkozók által számlázott, valamint a saját tevékenység során felmerült olyan közvetlen önköltségbe tartozó költségeket lehet kimutatni, amelyek azalapítás -áts zervezés befejezését követően a tevékenység során a bevételekben várhatóan megtérülnek.

- A kísérleti fejlesztés aktivált értékeként a jövőben hasznosítható, a kísérleti fejlesztés eredményének jövőbeni hasznosításakor az árbevételben megtérülö, a kísérleti fejlesztés eredménye érdekében felmerült olyan számlázott összeget és a saját tevékenység során felmerült közvetlen önköltségbe tartozó költségeket lehet figyelembe venni, amelyek aktiválható termékben - szellemi termék, tárgyi eszköz, készlet - nem vehetők számításba, mivel a létrehozott termék piaci - várható piaci - árát meghaladják. A kísérleti fejlesztés állományba vett aktivált értéke nem haladhatja meg azt az összeget, ami várhatóan megtérül a kapcsolódó jövőbeni gazdasági haszonból a további fejlesztési költségek, a várható termelési költségek, illetve a termék értékesítése során közvetlenül felmerülő értékesítési költségek levonása után.

- A kísérleti fejlesztés aktivált értékeként lehet kimutatni a megkezdett, de azüzleti év mérlegfordulónapjáig be nemfejezett kísérleti fejles ztés - a jövőben várhatóan megtérülő - közvetlen költségeit is. Ezesetben a kísérleti fejlesztés aktivált értéke nemcsak a kísérleti fejlesztés többletköltségeit foglalja magában, hanemazon termékek közvetlen költségeit is, amelyeket csak később, a kís érleti fejles ztés befejezésekor lehet a készletek, a tárgyi eszközök, a szellemi termékek között állományba venni a kísérleti fejles ztés aktivált értékének csökkentésével. Azalap - és alkalmazott kutatás költségei, valamint a kísérleti fejles ztés közvetett és általános költségei nem aktiválhatók" (2000. évi C. törvény).

Mindkét eszköz esetében a törvény szabályozza azon költségek körét, mely a bekerülési értékbe tartoznak, azonban a vállalkozásoknak van egy kis mozgásterük. Eldönthetik, hogy az alapítás-átszervezés, illetve a kísérleti fejlesztés költségeit aktiválják, vagy inkább költségként számolják el, ezzel is befolyásolva az eredmény alakulását ( 2 . ábra, következő oldal). Amennyiben a vállalkozás célja a tárgyévi eredmény növelése, akkor élhet az aktiválás lehetőségével, tehát a Számviteli törvény által meghatározott 
közvetlen költségeket aktiválja az alapítás-átszervezés, illetve a kísérleti fejlesztés mérlegsorokon. Ezen tételek után a vállalkozásnak lekötött tartalékot is képeznie kell az eredménytartalék terhére.

2. ábra. Alapítás, átszervezés és kísérleti fejlesztés hatása az eredményre

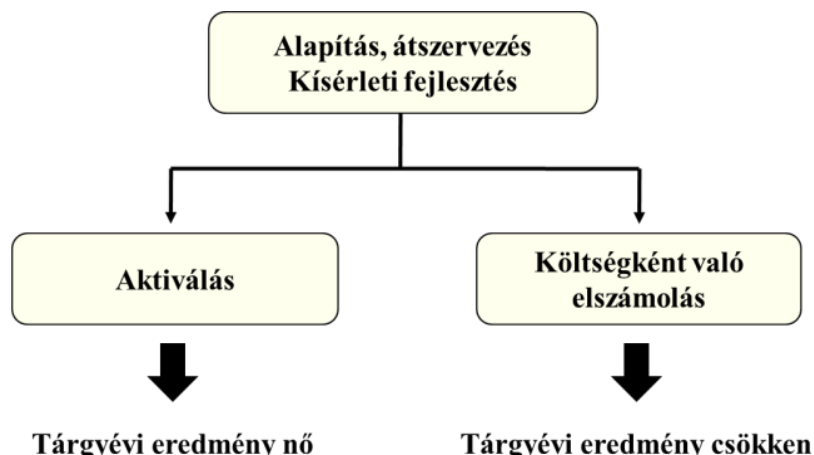

Forrás: Saját szerkesztés

\section{Értékelési eljárások - Értékcsökkenés}

A vállalkozásoknak a számviteli politika keretében kell szabályozniuk az értékcsökkenés elszámolásának rendjét. A befektetett eszközök között nyilvántartott immateriális javak és a tárgyi eszközök esetében a tartós használat következtében az eszközök értéke a fizikai és erkölcsi avulás következtében folyamatosan csökken, mely költségként jelenik meg a vállalkozás elszámolásaiban. Ezen eszközök esetében a bekerülési érték és a hasznos élettartam végén várható maradványérték közötti különbözetet az eszköz várható élettartamára kell felosztani. Az értékcsökkenés alakulását számos tényező befolyásolja (3. ábra).

\section{3. ábra. Értékcsökkenést befolyás oló tényezők}

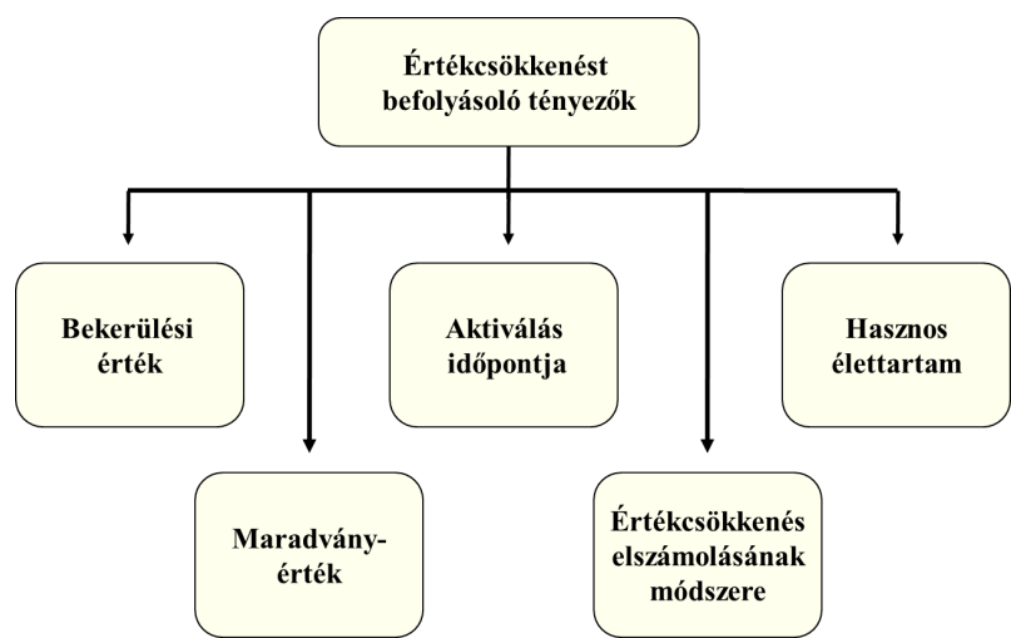

Forrás: Saját szerkesztés 
A bekerülési érték több részből áll. A beszerzéshez, létesítéshez, üzembe helyezéshez, raktárba történő szállításhoz kapcsolódó tételek számolhatók el a bekerülési érték részeként. Az eszközöket állományba venni az alábbi értékeken lehet:

- vásárlás $\rightarrow$ beszerzési ár,

- saját elóállítás $\rightarrow$ előállítás közvetlen önköltsége,

- nem pénzbeli vagyoni hozzájárulás, apport behozatal $\rightarrow$ társasági szerződés szerinti érték,

- térítés nélküli átvétel $\rightarrow$ állományba vétel időpontjában ismert piaci érték

- többlet, ajándék, hagyaték $\rightarrow$ a piaci érték és az eszköz beszerzéséhez közvetlenül kapcsolható költségeket tartalmazza.

A bekerülési értékét módosítja még az engedmény (-), a felárak (+), a beszerzéshez, üzembe helyezéshez, raktárba történő szállításhoz kapcsolódó szállítási és rakodási, alapozási, szerelési, üzembe helyezési költség (+), a közvetítői tevékenység ellenértéke $(+)$, a bizományi díj $(+)$, a beszerzéshez kapcsolódó adók és vámok $(+)$. A bekerülési értéknek nem része a folyamatos, biztonságos üzemeltetést biztosító javítási és karbantartási munkák költsége.

A maradványérték a hasznos élettartam végén várhatóan realizálható érték. Meghatározása során figyelembe kell venni a rendeltetésszerü használat jellemzőit a rendelkezésre álló információk alapján. A vállalkozás bizonyos eszközök esetében nulla maradványértéket is megállapíthat, ha az eszköz értéke a hasznos élettartam végén valószínüsíthetően nem lesz jelentős.

A hasznos élettartamnak nevezzük azt az időszakot, amely alatt a vállalkozás az eszközt időarányosan vagy teljesítményarányosan az eredmény terhére elszámolja. A hasznos élettartamot két elmélet alapján lehet meghatározni.

- A gazdálkodó a várható fizikai elhasználódást, erkölcsi avulást, az eszköz használatával kapcsolatos jogi és egyéb korlátozó tényezőket veszi figyelembe.

- A hasznos élettartamot a megtermelhető darabszám, elvégezhető teljesítmény vagy egyéb egységs zám alapján határozzák meg.

Az aktiválás időpontja szintén módosítja az eredmény alaku lását, mivel az értékcsökkenést csak az üzembe helyezést követően lehet elszámolni. Az üzembe helyezés időpontja az adott eszköz rendeltetés szerü hasznosításának a kezdő időpontja, melyet a vállalkozás köteles hitelt érdemlően dokumentálni és bizonyítani.

Az üzembe helyezéstől függetlenül nem számolható el terv szerinti értékcsökkenés a földterület, a telek, az erdő, a képzőművészeti alkotás, a régészeti lelet bekerülési értéke után, illetve az olyan eszközök esetében, melyek értékükből a használat során sem veszítenek, vagy értékük folyamatosan nő.

A terv szerinti értékcsökkenés elszámolása több módszerrel történhet, melyet a vállalkozás a tevékenység jellegéhez illően a számviteli politikában rögzít. A leírási módszer meghatározásánál a vállalkozás válas zthat, hogy az eszköz bruttó vagy nettó értéke alapján számolja-e el az értékcsökkenést.

Bruttó érték alapján lehetőség van lineáris, degresszív, teljesítményarányos, évek száma összege módszer szerinti és abszolút összegű leírásra.

- Lineáris leírás esetében az értékcsökkenés azonos összegü a hasznos élettartam évei során. 
- Degresszív módszernél az üzembe helyezést követően a legmagasabb a leírási kulcs, majd ezt követően folyamatosan csökken a hasznos élettartam során. A módszert akkor célszerü alkalmazni, ha az értékcsökkenés az üzembe helyezést követően jelentősebb, mint a későbbi időszakban.

- A teljesítményarányos módszer esetében az értékcsökkenést a hasznos élettartamre jutó teljesítmény alapján határozzák meg.

- Évek száma összege módszer alapján ez eszközt csökkenő mértékben kell leírni, a leírási kulcs évente változik az üzembe helyezést követően.

- Abszolút összegü leírásnál az eszköz bruttó értékét előre rögzített összegben írjuk le. Ebben az es etben nem lehet leírási kulcsot meghatározni.

A terv szerinti értékcsökkenés els zámolása során választhatjuk a nettó érték alapján történő leírást. Ez esetben alkalmazhatunk állandó kulcsot, illetve a termeléssel arányosan is csökkenthetjük az eszköz értékét.

- Állandó kulcs esetében a hasznos élettartam során csökkenő összegű értékcsökkenés kerül elszámolásra. Ennél a módszernél azonban mindig van maradványérték.

- A leírás történhet a termeléssel arányosan is, melyet ás ványi vagyon kitermelése során alkalmaznak.

Az értékcsökkenés módszerének megválasztása jelentős hatással lehet az eredményre is. A módszerek között hatalmas különbségek vannak, hogy a hasznos élettartam mely szakaszában mennyi értékcsökkenést számolnak el a vállalkozások, és ezáltal mennyivel csökken az eredményük.

\section{Értékelési eljárások - Értékvesztés meghatározása}

A vállalkozás eredményének alakulását nemcsak az értékcsökkenés, hanem az értékvesztés is befolyásolja.

- Értékvesztést kell els zámolni tulajdoni részesedést jelentő befektetésnél, hitelviszonyt megtestesítő értékpapíroknál, ha a könyv szerinti értéke és piaci értéke közötti különbözet (veszteség) tartósnak mutatkozik és jelentős összegü.

- A vevő, az adós minősítése alapján az üzleti év mérlegfordulónapján fennálló és a mérlegkészítés időpontjáig pénzügyileg nem rendezett követelések esetében is értékvesztést kell elszámolnia a gazdálkodónak, ha a követelés könyv szerinti értéke és a követelés várhatóan megtérülö összege közötti veszteség tartósnak mutatkozik és jelentős összegü.

- A gazdálkodónak értékvesztést kell elszámolnia, ha a vásárolt készlet bekerülési értéke, illetve könyv szerinti értéke tartósan és jelentősen magasabb, mint a mérlegkészítéskor ismert tényleges piaci értéke, illetve akkor, ha a saját termelésű készlet előállítási, illetve könyv szerinti értéke tartósan és jelentősen magasabb, mint a mérlegkészítéskor ismert és várható eladási ára.

Az értékvesztést, és annak hatását az eredményre több tényező együttesen alakítja, mint például a mérlegkészítés időpontja, a piaci érték meghatározás, a jelentős érték meghatározása (4. ábra). A mérlegkészítés időpontja jelentős szerepet tölt be az értékvesztések elszámolásában. Eddig az időpontig kell elvégezni a mérleg egyes tételeihez kapcsolódóan a megbízható és valós vagyoni helyzet bemutatásához szükséges értékelési feladatokat. A mérlegkészítés időpontját nagy mértékben befolyásolja a beszámolók 
közzétételének határideje. Éves, (sajátos) egyszerüsített éves beszámoló esetén az adott üzleti év mérlegforduló napjától számított 5. hónap utolsó napjáig kell közzétenni a beszámolót. Azoknál a vállalkozásoknak, melyeknek az üzleti éve meggyezik a naptári évvel, a beszámoló közzétételi határideje május 31-e. Mivel a mérlegkészítés időpontját a Számviteli törvény nem definiálja pontosabban, így nagy eltérések adódhatnak az aktuálisan rendelkezésre álló információk tükrében a piaci érték, vagy a várhatóan megtérülö érték meghatározásában.

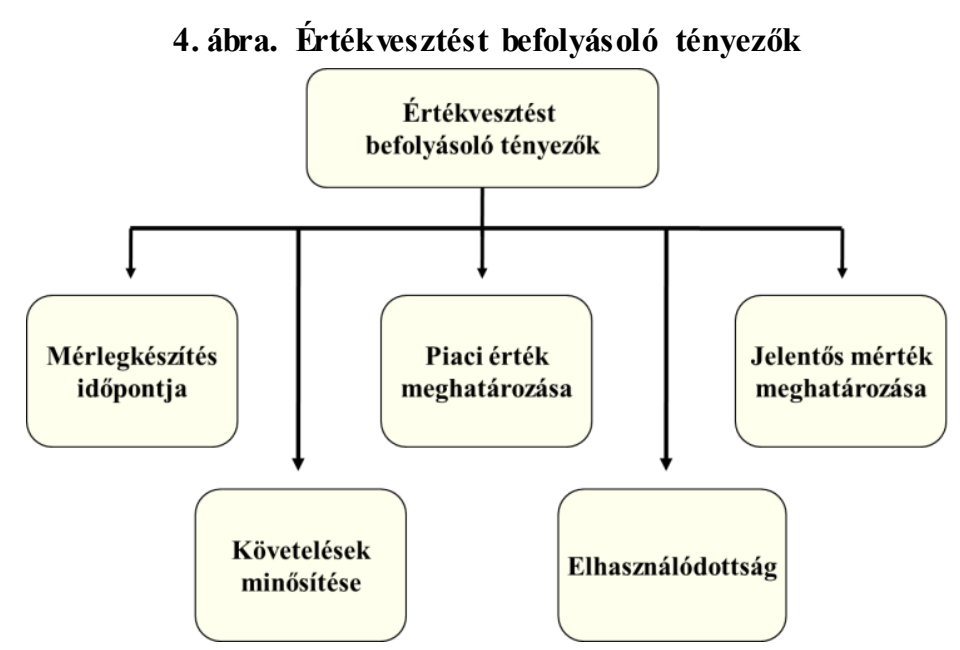

Forrás: Saját szerkesztés

Az értékvesztés elszámolásához szükség van a jelentős mérték meghatározására. A vállalkozóknak a számviteli politika keretén belül rögzíteniük kell, hogy a számviteli elszámolások során az értékelés szempontjából mi számít lényegesnek, jelentősnek, nem lényegesnek, nem jelentősnek. Ezen szabályokat a számviteli politika eszközök és a források értékelési szabályzata tartalmazza.

\section{Bekerülési érték meghatározása saját elóállítás esetén}

Saját termelés előállítása esetben az alábbi négy tényezőt kell figyelembe venni, ha az eredményre gyakorolt hatást szeretnénk bemutatni.

- Önköltség tartalma

- Önköltség számítás módszere

- Költségfelosztások módszere

- Készültségi fok

Az önköltségszámításra vonatkozóan a Számviteli törvény csupán keretszabályokat fogalmaz meg. A Számviteli törvény alapján az eszköz bekerülési (elöállítási) értékének részét képezik azok a költségek, amelyek:

- Az eszköz (termék) előállítása, üzembehelyezése, bővítése, rendeltetésének megváltoztatása, átalakítása, eredeti állagának helyreállitása során közvetlenül felmerültek,

- Az előállitással bizonyíthatóan szoros kapcsolatban voltak, továbbá 
- Az eszközre (termékre) megfelelő mutatók, jellemzők segítségével elszámolhatók (együttesen: közvetlen önköltség) (Sztv. 51. §.).

Az önköltség számítás esetében több kategória (5. ábra) számszerüsíthető attól függően, hogy a termelés érdekében felmerült költségek közül mit veszünk figyelembe az önköltség meghatározásánál. A közvetlen önköltség a felmerüléskor közvetlenül elszámolt költség termékegységre jutó része, mint például a közvetlen anyagköltség, a közvetlen bérek és járulékaik és az egyéb közvetlen költségek. A technológiai önköltség tartalmazza a gyártási általános költségek változó részét a közvetlen önköltségen kívül. A gyártási önköltség a korábbiakhoz még hozzáveszi a gyártási általános költségek fix részét is. A szükített önköltség a közvetlen önköltség, a gyártási általános költségek és a gyártással össze nem függő üzemi általános költségek összege. A teljes önköltség meghatározásakor pedig a gyártással össze nem függő vállalati általános költségeket is figyelembe kell venni. A pénzügyi számvitelben az értékelés alapjául szolgáló költség a gyártási önköltség.

\section{5. ábra. Önköltség kategóriák}

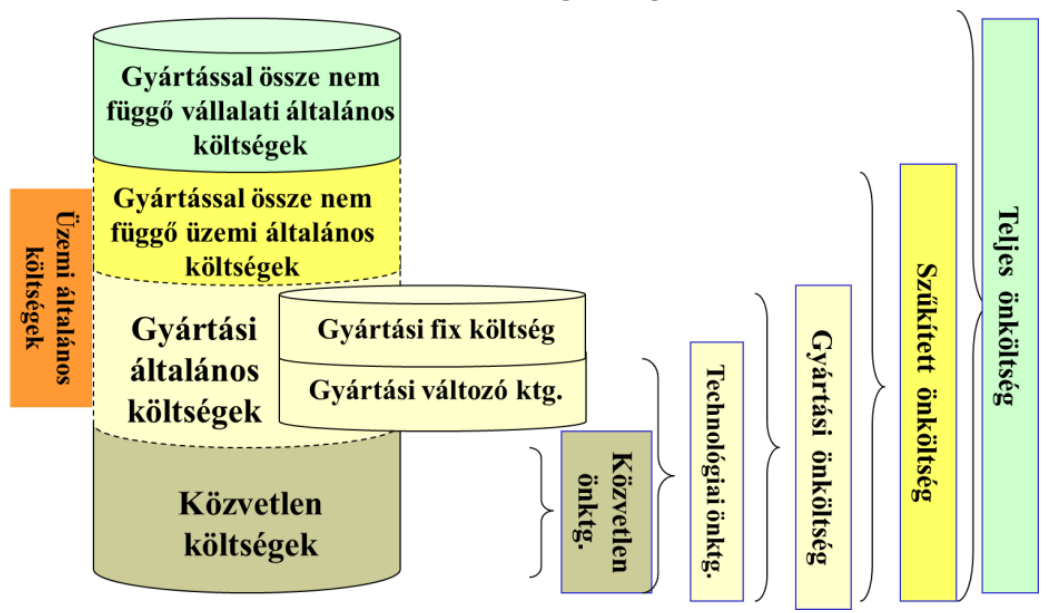

Forrás: Bosnyák et al., 2010, 85. oldal

Az önköltség számítás módszerének pontos meghatározását a vállalkozás a tevékenységének megfelelően alakítja ki. Ha az eladott áruk beszerzési értékével és a közvetített szolgáltatások értékével csökkentett árbevétel meghaladja 1md forintot, vagy a költségek összege meghaladja az 500 millió forintot a gazdálkodó köteles önköltségszámítási szabályzatot készíteni, melynek keretében meghatározza az önköltség számítás pontos módszerét. A gazdálkodók az önköltségszámítás rendjére vonatkozó belső szabályzat szerinti utókalkuláció módszerével végzik el a saját termelés értékelését.

Egyszerüsített éves beszámolót készítők esetén nem kötelezö önköltségszámítási szabályzatot készíteni, lehetőségük van

- a még várhatóan felmerülő költségekkel és a kalkulált haszonnal csökkentett eladási áron,

- a még várhatóan felmerülő költségek a teljesítési fok alapján arányosítással az önköltséget megállapítani.

Az önköltség alakulásában jelentős szerepet játszik, hogy a gazdálkodó a költségeket milyen módszer alapján osztja fel és milyen vetítési alapokat alkalmaz. 


\section{Árfolyampolitika}

A számviteli törvény lehetőséget ad a gazdálkodó szervezeteknek, hogy a valutapénztárba bekerülő valutakészletet, a devizaszámlára kerülő devizát, a külföldi pénzértékre szóló követelést, befektetett pénzügyi eszközt, értékpapírt, illetve kötelezettséget a bekerülés napjára, illetve a szerződés szerinti teljesítés napjára vonatkozó számviteli politikában meghatározott devizaárfolyamon átszámított forintértéken mutassa ki a könyvviteli nyilvántartásban, kivéve a forintért vásárolt valutát, devizát, amelyet a fizetett öszszegben kell felvenni, és amelynél a ténylegesen fizetett forint alapján kell a nyilvántartás ba vételi árfolyamot meghatározni. A választható árfolyamokat a 6 . ábra tartalmazza.

\section{6. ábra. Választható árfolyamok}

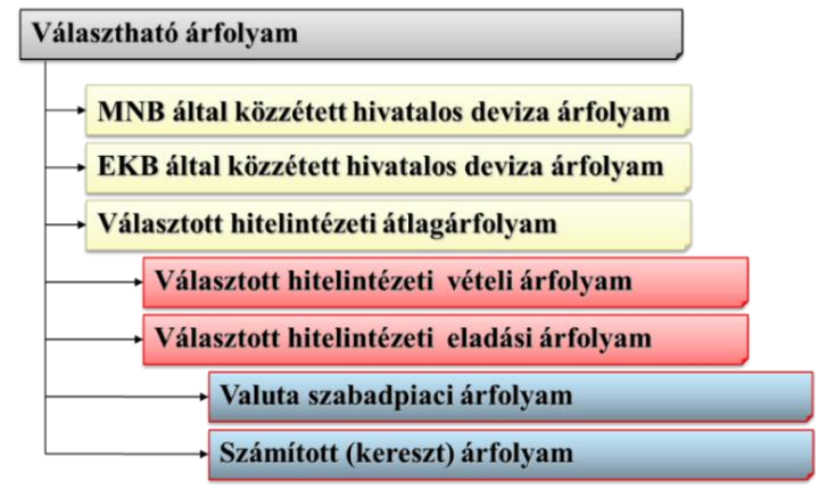

Év végi nem realizált árfolyam elhatárolása

Forrás: Saját szerkesztés

„Azon gazdasági események esetén, amelyeknél az ellenérték külföldi pénzértékben kerül meghatározásra, a külföldi pénzértékre szóló követelés, illetve kötelezettség forintértékének meghatározása során - a vállalkozó számviteli politikában rögzített döntése alapján - alkalmazható az általános forgalmi adóról szóló törvénynek az adóalap forintban történő megállapítására vonatkozó elöírásai szerinti árfolyam is" (Sztv. $60 . \S .(5 a))$.

\section{Tartalékpolitika}

\section{Céltartalék}

A céltartalékok az adózás előtti eredmény terhére képzett olyan passzívák, amelyek alapja az óvatosság és azösszemérés elve,

- pontosítja a tárgyévi eredményt, és a saját tőkét,

- fedezetet teremt a számviteli törvényben meghatározott jogcímek szerint a múltbeli és a következő év(ek)ben várhatóan felmerülő bizonytalan kimenetelü események kedvezőtlen hatására és kockázatára,

- összegük vagy esedékességük időpontja még bizonytalan, és azokra a vállalkozó a szükséges fedezetet más módon nem biztosította.

Érvényessége szerint kötelező vagy lehetőség. A jogcíme lehet várható kötelezettségekre, jövőbeni költségekre és egyéb okok miatti céltartalék. 
A vállalkozásnak a számviteli politikájában kell rögzítenie, a céltartalék képzésnél alkalmazott elveket, módszereket és az alátámasztó dokumentumokat. A képzés és felhasználás során a következeteség elvét alkalmazni kell.

A múltbeli ügyletekből származó, várhatóan felmerülő kötelezettségek és a jövőben várható költségek összege bizonytalan, így az eredményre gyakorolt hatás a vállalkozó döntésétől függ nagymértékben.

\section{2. Értékelési tartalék}

Fajtái:

- Értékhelyesbítés értékelési tartaléka

- Valós értékelés értékelési tartaléka.

Jelen cikkünkben csak az Értékhelyesbítés értékelési tartalékával foglalkozunk.

Értékhelyesbítés értékelési tartaléka:

- Az értékhelyesbítés sel azonos összegü saját forrás.

- A vállalkozó döntése szerint az eszközök meghatározott körének piaci értéken történő értékelése és a könyv szerinti értékelés különbözete.

- Számviteli politikában rögzíteni kell a piaci értéken történő értékelés válas ztását.

A számviteli törvény lehetőséget biztosít a gazdálkodóknak arra, hogy piaci értéken értékeljék eszközeik egy részét. A számviteli törvény szerint az értékhelyesbítés nem módosítja a könyv szerinti értéket, a mérlegben külön soron kerül kimutatásra. A piaci értéket minden évben felül kell vizsgálni és a kimutatott értékhelyesbítés összegét az aktuális piaci érték és a könyv szerinti érték különbözetének megfelelöen korrigálni kell. Az értékhelyesbítés els zámolása eredménysemleges.

\section{Fejlesztési tartalék}

A vállalkozóknak lehetőségük van adóévben eredménytartalékból fejlesztési céllal, jövőbeni beruházásaik megvalósításához tartalékot képezni. Az eredménytartaléknak az adóévben lekötött tartalékba átvezetett, kimutatott összegéta társasági adóalap számításakor az adózás előtti eredmény csökkentő jogcímeként lehet figyelembe venni. A fejlesztési tartalék képzése tulajdonképpen a TAO törvény szerint előrehozott értékcsökkenés, mely adóalap csökkentő tételnek minősül. A fejlesztési tartalékot az adózás előtti eredmény 50 százalékának, legfeljebb 500 millió forintnak megfelelö összegben lehet képezni. A fejlesztési tartalék képzése nem kötelező és csak azoknak a vállalkozásoknak van erre lehetőségük, melyeknek pozitív az adózás előtti eredményük.

A fejlesztési tartalék képzése a tárgyévi adózott eredményt növeli, a felhasználása során beszerzett eszközök értékcsökkenése adóalap növelö tétel lesz, így adózott eredményt csökkenti.

\section{Következtetések}

A számvitelről szóló 2000. évi C. törvény kereteiben határozza meg a gazdasági események els zámolási módját, azonban a gyakorlat, tapas ztalatokon alapuló gazdasági számvitel elindulhat a kreativitás irányába. Alapelv, amit a törvény nem tilt, azt „szabad”.

A gazdasági események értelmezése és rögzítése, az eredményre gyakorolt hatásának megítélése gyakran szubjektív értékelésen alapulhat.

A kreatív számvitel pozitív értelmezése 
- jogszabályok adta lehetőségek maximális kihasználása,

- vállalkozásnak leginkább megfelelő számviteli politika kialakítása, folyamatos gondozása,

- adó optimalizálása,

- kiskapuk keresése legális kereteken belül.

Az érdekeltek információ jutásához szükség van egységes szabályozókra. A jogszabályok adta választási lehetőségekröl való döntést a vállalkozásoknak a számviteli politikában kell rendezni. Az optimális megoldások kihasználására a törvényes keretek figyelembe vétele mellett megfelelő szakmai és gyakorlati tapasztalatok szükségesek.

\section{Felhasznált irodalom}

ACFE (2016): Report to the Nations on Occupational Fraud and Abuse - 2016 Global Fraud Study. Association of Certified Freud Examiners, https://www.acfe.com/ rttn2016/docs/2016-report-to-the-nations.pdf.

Bosnyák János - Gyenge Magdolna - Pavlik Lívia - Székács Péterné (2010): Vezetői Számvitel. Budapest, Saldo Zrt.

Cendrowski, Harry - James P. Martin - Louis W. Petro (2007): The Handbook of Fraud Deterrence, Hoboken (New Jersey), Wiley Publishing,.

ISA240 (2008): 240. témaszámú nemzetközi könyvvizsgálati standard. A könyvvizsgáló csalással összefüggö felelössége a pénzügyi kimutatások könyvvizsgálatánál. Nemzetközi Könyvvizsgálati és Bizonyosságot Nyújtó Szolgáltatási Standardok Testület. https://mkvk.hu/bundles/csmssite/mkvk/uploads/userfiles/files/hu/ letolthetoanyagok/dokumentumok/ISA_2010/ISA240.doc.

Lakatos László Péter - Kovács Dániel Máté - M darasiné Szirmai Andrea - Mohl Gergely - Rózsa Ildikó (2013): A nemzetközi pénzügyi beszámolási standardok elmélete és gyakorlata. Budapest, Magyar Könyvvizs gálói Kamara.

Naser, K. H. (1993). Creative Financial Accounting: Its Nature And Use. Hemel Hempstead: Prentice Hall.

PwC (2016): Javuló tendenciák vagy alábecsült veszélyek? - A gazdasági bünözés helyzete 2016-ban Magyarországon és világszerte. PwC Magyarország, https://www.pwc.com/hu/hu/sajtoszoba/2016/gazdasagi_bunozes_felmeres.html.

Veit Krisztina (2014): Szakmai szkepticizmus a könyvvizsgálatban; SZAKma 2014. júliusi-augus ztusi lapszám. http://szak-ma.hu/tanulmanyok/s zakmai-s zkepticizmus -a-konyvvizs galatban-100081

2000. évi C. törvény a számvitelröl. 